\title{
Central circulatory responses in normotensive and hypertensive pregnancy
}

\author{
MARTIN M. LeES \\ M.D., M.R.C.O.G. \\ Department of Obstetrics and Gynaecology, University of Edinburgh, and at \\ The Royal Infirmary, Edinburgh
}

\begin{abstract}
Summary
Haemodynamic responses in normotensive pregnancy in the antenatal phase show that cardiac output is elevated by the end of the first trimester, and remains elevated throughout pregnancy, although it may fall very slightly at the end of the third trimester of pregnancy. Heart rate remains virtually static throughout pregnancy, although it may fall very slightly at the end of the third trimester of pregnancy. Arterial blood pressure remains virtually unaltered. During labour in patients with traditional anaesthesia, cardiac output is elevated by $40 \%$ overall at the end of the labour, and this rise may be as much as $60 \%$ in the immediate post-partum period. Patients with epidural analgesia show no overall rise in cardiac output throughout labour. Following Caesarean section there may be massive rises in cardiac output.

In patients who become hypertensive as a result of pregnancy, there are marked individual patterns. These different groups show patients with elevated levels of cardiac output, patients with a pure elevation of systemic vascular resistance, and a third group in which there is elevation of both resistance and output.

It seems certain that different syndromes are occurring, the theoretical explanations for which are discussed.
\end{abstract}

\section{Introduction}

The physiological responses of the central maternal circulation to pregnancy, labour and Caesarean section have been investigated by a number of workers and have been reviewed by the author previously (Lees, Scott and Kerr, 1970; Lees et al., $1967 \mathrm{a}, \mathrm{b} ; 1968)$. An understanding of these changes has resulted in a more fundamental awareness of the changes which can occur in patients who develop hypertension as a result of becoming pregnant. Most of the observed changes in terms of physiological response can now be largely explained on a rational basis, but those changes which occur as a result of pregnancy hypertension are still exceedingly difficult to explain on account of the fact that the aetiology of this syndrome is still unclear.

\section{Patients and methods}

The methods which have been used to determine pressure and flow have previously been outlined in detail (Lees et al., 1967a, b). In addition to these techniques for measuring pressure and flow in the hypertensive group of patients, a Swann-Ganz catheter was floated into the pulmonary artery and wedged.

Two groups of patients were studied. Firstly, a group of primigravid patients in whom there was no evidence of any cardio-respiratory disease, whose ages ranged from 22 to 30 years, and whose pregnancies were uncomplicated. Their central haemodynamic responses were measured and compared against a group of primigravidae of the same age range who had no evidence of previous disease that was known, and in whom the gestation periods ranged from the 36th to the 41st weeks of pregnancy. Each patient had at least $4 \mathrm{BP}$ recordings taken monthly in the normotensive range, the findings being not greater than $130 \mathrm{mmHg}$ systolic, and 80 $\mathrm{mmHg}$ diastolic before the onset of hypertension. The critical minimal level of elevation of diastolic blood pressure was a recording of $\geqslant 90 \mathrm{mmHg}$ on at least 4 occasions. All patients had at least one $\mathrm{g}$ of protein in the urine (Esbach). None of them had any drug treatment before investigation. The parameters of systemic arterial pressure, right atrial pressure, cardiac output, heart rate, pulmonary artery and pulmonary wedge pressure were measured during 3 consecutive 20 -min periods beginning with the patient lying in the lateral horizontal position. Following this initial period the patient lay supine for a further $20 \mathrm{~min}$ and the study ended with the patient lying in the lateral position for a final 20-min period.

\section{Results}

The data for the normotensive and hypertensive groups which were studied are given in Table 1 . The individual haemodynamic patterns of 2 patients with virtually identical mean systemic arterial pressures but differing vascular responses are shown in Table 2. Systemic and pulmonary vascular responses are 
TABLE 1. Average mean data of pressure and flow in normotensive and hypertensive patients

\begin{tabular}{|c|c|c|c|c|c|c|c|}
\hline & Position & $\begin{array}{l}\text { Systolic } \\
\text { arterial } \\
\text { pressure } \\
(\mathrm{mmHg})\end{array}$ & $\begin{array}{c}\text { Mean } \\
\text { arterial } \\
\text { pressure } \\
(\mathrm{mmHg})\end{array}$ & $\begin{array}{l}\text { Diastolic } \\
\text { arterial } \\
\text { pressure } \\
(\mathrm{mmHg})\end{array}$ & $\begin{array}{l}\text { Cardiac } \\
\text { output } \\
(1 / \mathrm{min})\end{array}$ & $\begin{array}{c}\text { Heart } \\
\text { rate } \\
\text { (beats } / \mathrm{min} \text { ) }\end{array}$ & $\begin{array}{c}\text { Mean systemic } \\
\text { vascular } \\
\text { resistance } \\
\left(\mathrm{dyn} / \mathrm{sec} / \mathrm{cm}^{5}\right)\end{array}$ \\
\hline $\begin{array}{l}\text { Hypertensive subjects } \\
\quad(n=14)\end{array}$ & $\begin{array}{l}\text { Lateral } \\
\text { Supine }\end{array}$ & $\begin{array}{l}146 \\
143\end{array}$ & $\begin{array}{l}111 \\
110\end{array}$ & $\begin{array}{l}94 \\
93\end{array}$ & $\begin{array}{l}5 \cdot 83 \\
5 \cdot 58\end{array}$ & $\begin{array}{l}83 \\
86\end{array}$ & $\begin{array}{l}1590 \\
1658\end{array}$ \\
\hline $\begin{array}{l}\text { Normotensive subjects } \\
\quad(n=14)\end{array}$ & $\begin{array}{l}\text { Lateral } \\
\text { Supine }\end{array}$ & $\begin{array}{l}112 \\
114\end{array}$ & $\begin{array}{l}85 \\
84\end{array}$ & $\begin{array}{l}72 \\
70\end{array}$ & $\begin{array}{l}5 \cdot 93 \\
4 \cdot 96\end{array}$ & $\begin{array}{l}84 \\
82\end{array}$ & $\begin{array}{l}1145 \\
1367\end{array}$ \\
\hline
\end{tabular}

TABle 2. Average mean data in 2 patients of the hypertensive group

\begin{tabular}{|c|c|c|c|c|c|c|c|}
\hline Subject & Position & $\begin{array}{l}\text { Systolic } \\
\text { arterial } \\
\text { pressure } \\
(\mathrm{mmHg})\end{array}$ & $\begin{array}{c}\text { Mean } \\
\text { arterial } \\
\text { pressure } \\
(\mathrm{mmHg})\end{array}$ & $\begin{array}{l}\text { Diastolic } \\
\text { arterial } \\
\text { pressure } \\
(\mathrm{mmHg})\end{array}$ & $\begin{array}{c}\text { Cardiac } \\
\text { output } \\
(1 / \mathrm{min})\end{array}$ & $\begin{array}{c}\text { Heart } \\
\text { rate } \\
\text { (beats } / \mathrm{min} \text { ) }\end{array}$ & $\begin{array}{c}\text { Mean systemic } \\
\text { vascular } \\
\text { resistance } \\
\left(\text { dyn } / \mathrm{sec} / \mathrm{cm}^{5}\right)\end{array}$ \\
\hline A & $\begin{array}{l}\text { Lateral } \\
\text { Supine }\end{array}$ & $\begin{array}{l}171 \\
173\end{array}$ & $\begin{array}{l}128 \\
130\end{array}$ & $\begin{array}{l}101 \\
102\end{array}$ & $\begin{array}{l}8 \cdot 76 \\
8 \cdot 77\end{array}$ & $\begin{array}{l}90 \\
90\end{array}$ & $\begin{array}{l}1191 \\
1174\end{array}$ \\
\hline B & $\begin{array}{l}\text { Lateral } \\
\text { Supine }\end{array}$ & $\begin{array}{l}165 \\
170\end{array}$ & $\begin{array}{l}135 \\
138\end{array}$ & $\begin{array}{l}120 \\
125\end{array}$ & $\begin{array}{l}6.91 \\
5.64\end{array}$ & $\begin{array}{l}100 \\
108\end{array}$ & $\begin{array}{l}1595 \\
1892\end{array}$ \\
\hline
\end{tabular}

outlined in Table 3 where it will be noted that the levels of pulmonary arterial pressures are within the non-pregnant range. There are markedly different central haemodynamic patterns with evidence of a raised output state associated with well marked tachycardia, hypertension associated with a raised systemic vascular resistance, as well as a combination of raised vascular resistance and raised output. Data for cardio-pulmonary blood volume values are given in Table 4.

TABLE 3. Systemic and pulmonary vascular pressures and flow in 4 patients with acute pregnancy hypertension

\begin{tabular}{lrrrr}
\hline \multicolumn{1}{c}{ Patient } & C & D & E & F \\
\hline $\begin{array}{l}\text { Systemic arterial } \\
\text { pressure (mmHg) }\end{array}$ & & & & \\
$\quad$ Systolic & 158 & 139 & 132 & 164 \\
$\quad$ Diastolic & 108 & 95 & 92 & 114 \\
$\quad$ Mean & 118 & 110 & 108 & 130 \\
Pulmonary arterial & & & & \\
pressure (mmHg) & 19 & 26 & 22 & 19 \\
$\quad$ Systolic & 10 & 15 & 13 & 12 \\
$\quad$ Diastolic & 14 & 19 & 17 & 15 \\
$\quad$ Mean & $7 \cdot 63$ & $9 \cdot 10$ & $7 \cdot 45$ & $6 \cdot 12$ \\
Cardiac output (l/min) & & 85 & 102 & 88 \\
Heart rate (beats/min) & 123 & 85 & & \\
\hline
\end{tabular}

TABLE 4. Cardio-pulmonary blood volume in association with pregnancy hypertension

\begin{tabular}{lcc}
\hline \multicolumn{1}{c}{ Group } & $\begin{array}{c}\text { No. of } \\
\text { patients }\end{array}$ & $\begin{array}{c}\text { Cardio-pulmonary } \\
\text { blood volume (ml) }\end{array}$ \\
\hline $\begin{array}{l}\text { Normotensive } \\
\text { Hypertensive }\end{array}$ & 14 & 346 (range 242-530) \\
\hline
\end{tabular}

\section{Discussion}

The physiological changes which occur in the primigravid patient in response to pregnancy have been outlined in detail previously (Lees et al. 1967a, b, 1968, 1970). Ueland, Novy and Metcalfe (1972) have shown that in certain patients at or iust past term there may be a slight further reduction ito cardiac output, probably explained by the fact that the weight of the gravid uterus at this time is increased. In general, therefore, cardiac output is elevated after the end of the first trimester of pregnancy and remains elevated throughout pregnancy except for slight reduction towards term. Arterial blood pressure remains virtually constant and heart rate rises, but only very slightly. Throughout labour it has been shown (Hansen and Ueland, 1969) that cardiac output may rise by as much as $40 \%$ in patients who have traditional analgesia. Lees et al. (1970) have shown that where epidural analgesia has been given, there is no cumulative rise in cardiac output throughout labour. Various studies have been carried out during Caesarean section and have been previously reviewed (Lees et al., 1968). These studies have shown variable rises in cardiac output of up to $80-90 \%$ following delivery, and that these rises are extremely abrupt.

For many years it has been accepted that systemic arterial hypertensive diseases are associated in general with an increase in systemic vascular resistance. However, in recent years it has become more clear that there are various types of arterial hypertension and these may be associated with different haemodynamic patterns. Widimsky (Widimsky, Fejfarova and Fejfar, 1957) was the first to show that in mild, early essential hypertension and in juvenile 
hypertension there was a raised cardiac output. Widimsky showed furthermore, that this raised output state was not maintained when the patients with juvenile hypertension were followed-up despite the fact that they were still hypertensive. Therefore, it would seem that the elevation in output is probably just a phase in the development of hypertension rather than being causative in the eventual development of hypertension. Such findings of a hyperkinetic circulation with raised cardiac output have also been described in association with acute glomerular nephritis (de Fazio et al., 1959) and with renovascular hypertensive states (Widimsky et al., 1957; Frohlich et al., 1968; Tarazi et al., 1969; Ulrychs et al., 1969).

In the initial assessment of the pregnant hypertensive group, the main findings pointed to a raised systemic vascular resistance. However, within this group were 2 patients in whom there were elevations of cardiac output despite the fact that they had levels of heart rate which were within the normotensive range for the last trimester of pregnancy. In 4 patients in whom pulmonary arterial pressures were monitored in addition to the other parameters, it is clear that there were quite different forms of haemodynamic response. In one, there was an elevated cardiac output as a result of a very elevated heart rate. In another, with elevated cardiac output, heart rate was within normal limits, and yet in a third, there was elevated systemic pressure which resulted from a raised output and raised vascular resistance. In terms of pulmonary arterial pressure in these 4 patients, the levels of pressure were not significantly raised above levels which have been reported previously for the third trimester of pregnancy (Werko, 1950; Bader et al., 1955). Cardio-pulmonary blood volume levels showed values minimally raised above the normotensive group.

It therefore seems that there are a number of different and conflicting underlying patho-physiological patterns in association with pregnancy hypertension. The likely explanation for these differences is almost certainly on account of different aetiologies. What is the significance of a raised cardiac output in hypertension? It has usually been thought that vasoconstriction has been the myogenic response to an increased cardiac output and explains the elevation of systemic vascular resistance. If propranolol is given to individuals with reno-vascular hypertension the cardiac output is lowered but arterial blood pressure remains the same and therefore this is due to an elevation of systemic vascular resistance. The increase in cardiac output, therefore, is not in this instance directly responsible for the maintenance of hypertension. Previous work in patients with labile hypertension, essential hypertension, reno-vascular hypertension and in those with renal parenchymal disease and phaechromocytoma has shown that there is often an elevation of heart rate. This elevation of heart rate is due either to an increased outflow along the cardio-accelerator nerves or to failure of the cardio-inhibitory reflexes. Initially, it was thought that there was an increased outflow along the cardioaccelerator nerve fibres because, following the administration of intravenous propranolol, there was a diminution of heart rate in patients with hypertension, as opposed to normotensive individuals. However, it now seems likely that there is a failure of cardio-inhibitory reflexes on account of the fact firstly that there is a reduction in the increase in heart rate that one would expect in response to atropine in young labile hypertensives and, secondly, that there is less than normal cardiac slowing following bolus injections of angiotensin.

There are 4 possible mechanisms which might explain increased systemic flow in hyperkinetic circulatory states. One, the intravascular volume of the cardio-pulmonary circulation may be increased owing to redistribution of peripheral vascular beds. This may occur to a certain extent but probably only occurs in a limited way except in situations of extreme peripheral vasoconstriction. Two, there may be a circulating humoral agent. There has been much controversy about the existence of circulating pressor agents, and there has been conflicting evidence about it. Theoretically, one would expect such an agent to be present, but the evidence so far is somewhat equivocal. Three, there may be increased adrenergic activity which may account for the alteration in neural circulatory control in hypertensive states. Four, there may be increased responsiveness of the myocardium and smooth muscle of the general vasculature owing to the presence of either hormonal or neural stimuli.

The alterations which may occur in the pulmonary circulation are clearly conflicting. Werko (1950) and Bader et al (1955) demonstrated that pulmonary arterial pressure in hypertensives showed similar values to normotensives except where there was severe pre-eclampsia when there was an increased pulmonary resistance. Littler et al. (1973) first suggested that there may be a low-grade process of intravascular coagulation occurring in the pulmonary arterioles which might explain this finding.

The control of the central circulation depends upon the interaction of a vast number of very finely adjusted systems. Central haemodynamic measurements are coarse but essential guides to the further understanding of complex alterations in the central circulation of pregnant hypertensive patients, the underlying causation of which remains to be defined. 


\section{Acknowledgment}

I wish to thank Dr B. J. Kirby, Senior Lecturer in Medicine, University of Exeter, for technical assistance and advice.

\section{References}

Bader, R.A., Bader, M.E., Ross, D.J. \& Braunwald, E. (1955) Hemodynamics at rest and during exercise in normal pregnancy as studied by cardiac catheterization. Journal of Clinical Investigation, 34, 1524.

De Fazio, V., Christensen, R.C., Regan, T.J., Baer, L.J., Morita, Y. \& Hellems, H.K. (1959) Circulatory changes in acute glomerulonephritis. Circulation, 20, 190.

Frohlich, E.D., Ulrychs, M., TARAZI, R.C., Dustan, H.P. \& PAGE, I.H. (1968) Hemodynamics of renal arterial diseases and hypertension. American Journal of the Medical Sciences, 255, 29.

Hansen, J.M. \& UnLAND, K. (1969) Maternal cardiovascular dynamics. American Journal of Obstetrics and Gynecology, $103,1$.

Lees, M.M., ScotT, D.B. \& KerR, M.G. (1970) Haemodynamic changes associated with labour. Journal of Obstetrics and Gynaecology of the British Commonwealth, 77, 29.

Lees, M.M., ScotT, D.B., Kerr, M.G. \& TAYlor, S.H. (1967a) The circulatory effects of recumbent postural change in late pregnancy. Clinical Science, 32, 453.

Lees, M.M., Scott, D.B., Slawson, K.B. \& KerR, M.G. (1968) Haemodynamic changes during Caesarean section. Journal of Obstetrics and Gynaecology of the British Commonwealth, 74, 319.
Lees, M.M., Taylor, C.H., Scott, D.B. \& KerR, M.G. (1967b) A study of cardiac output at rest throughout pregnancy. Journal of Obstetrics and Gynaecology of the British Commonwealth, 74, 319.

LitTler, W.A., BonNaR, J., Redman, C.W.G., Beilin, L.J. \& LEE, G. DE J. (1973) Reduced pulmonary arterial compliance in hypertensive pregnancy. Lancet, $\mathbf{i}, 1274$.

TaRazi, R.C., Dustan, H.P., Frohlich, E.D. \& Gifford Jr, R.W. (1969) Value of plasma volume measurement in hypertensive diseases. Abstract. Journal of Clinical Investigation, 48, 83A.

UELAND, K. \& HANSEN. J.M. (1969) Maternal cardiovascular dynamics III. Labor and delivery under local and caudal analgesia. American Journal of Obstetrics and Gynecology, 163, 8.

Ueland, K., Novy, M.J. \& Metcalfe, J. (1972) Hemodynamic responses of patients with heart disease to pregnancy and exercise. American Journal of Obstetrics and Gynecology, 113, 47.

Ulrychs, M., Frohlich, E.D., Tarazi, R.C., Dunstan, H.P. \& PAGE, I.M. (1969) Cardiac output and distribution of blood volume in central and peripheral circulations in hypertensive and normotensive man. British Heart Journal, 31, 570.

Widimsky, J., Fejfarova, M.H. \& Fejfar, Z. (1957) Changes of cardiac output in hypertensive disease. Cardiologia (Basel), 31, 381.

Werko, L. (1950) CIBA Foundation Symposium on Toxaemias of Pregnancy: Human and Veterinary. P. 155. Churchill, London. 